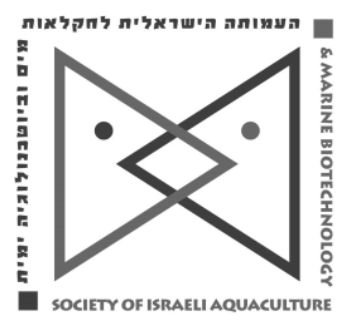

The IJA appears exclusively as a peer-reviewed on-line open-access journal at http://www.siamb.org.il. To read papers free of charge, please register online at registration form.

Sale of IJA papers is strictly forbidden.

\title{
Effects of Different Lipid Sources on the Growth Performance and Muscle Fatty Acid Composition of Juvenile Anguilla marmorata
}

\author{
Lian Gan ${ }^{1,2 *}$, Xiao-xia $\mathrm{Li}^{2}$, Li Liu Zhou ${ }^{2}$, Shao Xuan $\mathrm{Zhu}^{2}$, Xue Ming \\ Dan $^{2}$, Li Liu', Hui-juan Tang ${ }^{2}$ Gui feng $\mathrm{Li}^{3}$, Guang jun Wang ${ }^{1 *}$ \\ ${ }^{1}$ Key Laboratory of Tropical \& Subtropical Fishery Resource Application \\ and Cultivation, Ministry of Aqriculture, P.R.China, Guangzhou, China \\ ${ }^{2}$ Marine Science College, South China Agricultural University, Guangzhou, \\ ${ }^{3}$ Life science of college, Sun yat-sen University, Guangzhou, China
}

Keywords: lipid sources; Anguilla marmorata; growth performance; fatty acid

\begin{abstract}
The aim of this study was to investigate the effects of different oils on growth performance of juvenile Anguilla marmorata. Five isonitrogenous and isoenergetic experimental diets were formulated to contain fish oil (FO), sunflower oil (SFO), peanut oil (PO), corn oil (CO) and soybean oil (SBO), respectively, as lipid sources each at an inclusion level of $50 \mathrm{~g} / \mathrm{kg}$. The diets were fed to apparent satiation for 10 weeks, twice a day to triplicate tanks of 30 fish each with an initial body weight $6.00 \pm 0.06 \mathrm{~g}$. Weight gain (WG) and specific growth rate (SGR) of fish fed the FO and SBO diets were markedly higher than those fed the CO diet, while no other difference in WG and SGR were observed among other treatments. Fish fed FO and SBO diets had better feed utilization than the other diet fish groups. Muscle of fish fed the FO diet had significantly higher levels of $\mathrm{C}_{2} 0: 5 n-3$ and $n-3 / n-6$ ratio compared with fish fed vegetable oil (VO) diets, while muscle n- 6 PUFA and C18:2n-6 content showed an opposite trend. The present results suggest that soybean oil is a suitable replacement for fish oil for Anguilla marmorata.
\end{abstract}

* Corresponding author. email address: ganlian@scau.edu.cn; gjwang@prfri.ac.cn 


\section{Introduction}

River eels, such as the Japanese eel (Anguilla japonica), European eel (Anguilla anguilla) and American eel (Anguilla rostrata), have been cultured under extensive or intensive aquaculture systems mainly in Asia. (Lee et al., 2003). In 2011 global river eel production was 255,284 tons (FAO, 2010). In recent years, the catch of glass eel of European, American, and Japanese eels has markedly decreased due to environmental destruction and overfishing (Geejm et al., 2009, Tsukamoto et al., 2009). Some farmers have tried to culture other inexpensive eel species (Luo et al., 2013). Anguilla marmorata, one of the most widely distributed species among the anguillids, are found throughout most of the tropical and sub-tropical western Pacific and Indian Oceans. Anguilla marmorata is an important species that can replace Japanese and European eel in China, due its low price and fast growth (Luo et al., 2013).

Lipids are essential as a source of energy, as structural components of biomembranes, eicosanoid percursors, carriers of fat-soluble vitamins, hormones, vitamin D, and as enzyme co-factors (Higgs and Dong, 2000). Lipid used for energy can also spare dietary proteins and improve growth performance (Ghanawi et al., 2011). Fish oil (FO) is traditionally used as the principal lipid source in commercial fish feeds, as it contains abundant quantities of mono-unsaturated fatty acids (MUFA) used by fish as a metabolic energy source and n-3 highly unsaturated fatty acids ( $n-3$ HUFA) that are necessary for stress resistance and development of immunity in fish (Montero et al., 2003). Annual FO production has not increased beyond 1.5 million tons per annum since 1980, while the global consumption of FO by the rapidly growing aquaculture industry has increased significantly over the past few decades,. FO supply may not be able to meet demands in the near future (Turchini et al., 2009). The use of alternative lipid sources to replace FO has become a priority in the aquaculture industry. Vegetable oils are suitable alternatives to fish oil in fish diet due to their abundance and relatively stable prices (Asdari et al., 2011). Intensive research activities are being conducted globally to evaluate alternative lipid sources for fish (Turchini et al., 2009).

Information associated with the use of vegetable oils in Anguilla marmorata juvenile diets is scarce. The principal objective of this study was to investigate the effects of different vegetable oils on the growth performance, liver histology, and muscle fatty acid composition of Anguilla marmorata juveniles.

\section{Materials and Methods}

Experimental diet and diet preparation. Five isonitrogenous and isolipidic experimental diets, varying only in the dietary lipid source, were formulated to contain $48 \%$ protein. Fish oil (FO) was substituted by sunflower oil (SFO), peanut oil (PO), corn oil (CO), or soybean oil (SBO) respectively (Table 1 ). Diets were prepared and stored as previously reported (Engin and Carter, 2001). Fatty acid composition of diets are shown in Table 2.

Experimental procedures. Anguilla marmorata juveniles (initial wet weight $6.00 \pm 0.06 \mathrm{~g}$ ) from the Philippines were used in this experiment. The eels were acclimated to experimental conditions for 2 weeks prior to onset of the experiment. Thirty healthy fish were randomly distributed into each of the 15 experimental fiberglass tanks $(300 \mathrm{~L})$ connected to a recirculation system. 
Table 1. Formulation and proximate composition of the experimental diets (\%)

\begin{tabular}{|c|c|c|c|c|c|c|}
\hline \multirow{2}{*}{ Ingredients } & & \multicolumn{5}{|l|}{ Diets } \\
\hline & & $F O$ & SFO & $P O$ & $\mathrm{CO}$ & SBO \\
\hline \multirow{2}{*}{\multicolumn{2}{|c|}{$\begin{array}{l}\text { Fish meal } \\
\text { Brewers' yeast }\end{array}$}} & 68 & 68 & 68 & 68 & 68 \\
\hline & & 2.5 & 2.5 & 2.5 & 2.5 & 2.5 \\
\hline \multicolumn{2}{|l|}{ a-starch } & 22.6 & 22.6 & 22.6 & 22.6 & 22.6 \\
\hline \multicolumn{2}{|l|}{ Mineral premix } & 0.5 & 0.5 & 0.5 & 0.5 & 0.5 \\
\hline \multicolumn{2}{|l|}{ Vitamin premix } & 0.5 & 0.5 & 0.5 & 0.5 & 0.5 \\
\hline \multicolumn{2}{|c|}{ Choline chlorine $(50 \%)$} & 0.2 & 0.2 & 0.2 & 0.2 & 0.2 \\
\hline \multicolumn{2}{|c|}{ Monocalcium phosphate } & 0.5 & 0.5 & 0.5 & 0.5 & 0.5 \\
\hline \multicolumn{2}{|c|}{ VC Ascorbic acid } & 0.1 & 0.1 & 0.1 & 0.1 & 0.1 \\
\hline \multicolumn{2}{|l|}{ Betaine } & 0.1 & 0.1 & 0.1 & 0.1 & 0.1 \\
\hline \multicolumn{2}{|l|}{ Fish oil } & 5 & & & & \\
\hline \multicolumn{2}{|l|}{ Sunflower oil } & & 5 & & & \\
\hline \multicolumn{2}{|l|}{ Peanut oil } & & & 5 & & \\
\hline \multicolumn{2}{|l|}{ Corn oil } & & & & 5 & \\
\hline \multicolumn{2}{|l|}{ Soybean oil } & & & & & 5 \\
\hline \multicolumn{2}{|l|}{ Total } & 100 & 100 & 100 & 100 & 100 \\
\hline \multicolumn{7}{|c|}{ Nutrient contents (\%, dry weight basis) } \\
\hline \multicolumn{2}{|c|}{ Moisture } & 6.44 & 6.87 & 7.5 & 7.48 & 6.5 \\
\hline \multicolumn{2}{|l|}{ Crude protein } & 47.50 & 47.77 & 47.90 & 48.25 & 48.12 \\
\hline Crude lipid & & 8.09 & 7.69 & 7.88 & 7.88 & 8.39 \\
\hline $\begin{array}{l}\text { Vitamin premix ( } \\
\mathrm{K} \text { (menadione soc } \\
\text { pantothenate, } 15 \\
\mathrm{mg} / \mathrm{kg} ; \text { niacin, } 20 \\
\text { inositol, } 400 \mathrm{mg} / \\
\text { Mineral premix ( } \\
\mathrm{ZnSO}_{4} \cdot 7 \mathrm{H}_{2} \mathrm{O}(22 . \\
(45.6 \% \mathrm{Se}), 1.0\end{array}$ & $\begin{array}{l}\mathrm{g} / \mathrm{kg} \text { or } \\
\text { ium bisul } \\
\mathrm{mg} / \mathrm{kg} ; \\
\mathrm{mg} / \mathrm{kg} ; \\
\mathrm{g} . \\
\mathrm{gg} / \mathrm{kg} \text { of } \\
\% \mathrm{Zn} \text { ), } \\
\mathrm{CoCl}_{2} \cdot 6 \mathrm{H}\end{array}$ & $\begin{array}{l}\text { vitamin } \mathrm{A} \text {, } \\
\mathrm{e}), 30 \mathrm{mg} / \mathrm{l} \\
\text { in }(1 \%), 0 . \\
\text {-idoxine, } 30 \\
\text { ): } \mathrm{MnSO}_{4} \cdot \mathrm{f} \\
0 ; \mathrm{MgSO}_{4} \cdot 7 \\
24.8 \% \mathrm{Co} \text {, }\end{array}$ & $\begin{array}{l}6000 \mathrm{I} \\
\mathrm{kg} ; \text { thia } \\
8 \mathrm{mg} / \mathrm{k} \\
\mathrm{mg} / \mathrm{kg} \\
\mathrm{H}_{2} \mathrm{O}(3 \\
7 \mathrm{H}_{2} \mathrm{O} \text { ( } \\
10.0 .\end{array}$ & $\begin{array}{l}\text {; vitamin } \mathrm{D}, 40 \\
\text { in, } 40 \mathrm{mg} / \mathrm{kg} \text {; } \\
\text {; folic acid, } 15 \\
\text { ascorbic acid ( } \\
\begin{array}{l}5 \% \mathrm{Mn}), 40.0 \\
95 \% \mathrm{Mg}), 0.0\end{array}\end{array}$ & $\begin{array}{l}0 \mathrm{IU} ; \text { vitan } \\
\text { riboflavin, } 5 \\
\mathrm{mg} / \mathrm{kg} ; \text { vita } \\
\text { hosphate, } \\
\mathrm{CuSO}_{4} \cdot 5 \mathrm{H} \\
\% ; \mathrm{KI}^{2}(76\end{array}$ & $\begin{array}{l}250 \mathrm{IU} ; \text { vitamin } \\
/ \mathrm{kg} ; \mathrm{d} \text {-calcium } \\
312(0.1 \%), 0.05 \\
200 \mathrm{mg} / \mathrm{kg} ; \\
5.4 \% \mathrm{Cu}), 10.0 \\
\text { I), } 5.0 ; \mathrm{Na}_{2} \mathrm{SeO}\end{array}$ \\
\hline Fatty acid & Diets & 2 & & & & \\
\hline racly acia & $F O$ & SFO & & $P O$ & $\mathrm{CO}$ & SBO \\
\hline C14:0 & 3.36 & 1.59 & & 1.31 & 1.38 & 1.71 \\
\hline $\mathrm{C} 16: 0$ & 19.44 & 14.43 & & 16.76 & 19.53 & 16.82 \\
\hline C18:0 & 4.67 & 5.42 & & 4.46 & 3.26 & 5.09 \\
\hline C20:0 & / & / & & 0.80 & / & I \\
\hline$C 22: 0$ & / & / & & 1.22 & / & / \\
\hline$C 24: 0$ & / & / & & 0.59 & / & / \\
\hline$\Sigma S F A$ & 27.47 & 21.44 & & 25.14 & 24.17 & 23.62 \\
\hline C16:1 & 4.74 & 2.37 & & 2.06 & 2.30 & 2.06 \\
\hline C18:1 & 27.36 & 24.60 & & 32.43 & 27.61 & 25.10 \\
\hline C20:1 & / & / & & 2.35 & 2.06 & / \\
\hline$\Sigma$ MUFA & 32.10 & 26.97 & & 36.84 & 31.97 & 27.16 \\
\hline C18:3n-3 & 2.00 & / & & / & 0.74 & 3.42 \\
\hline$C 20: 5 n-3$ & 8.28 & 5.13 & & 4.8 & 5.43 & 4.85 \\
\hline$C 22: 6 n-3$ & 9.86 & 7.43 & & 7.22 & 7.84 & 7.29 \\
\hline$\Sigma \mathrm{n}-3 \mathrm{PUFA}$ & 20.14 & 12.56 & & 12.02 & 14.01 & 15.56 \\
\hline$C 18: 2 n-6$ & 12.07 & 34.31 & & 21.38 & 28.83 & 29.35 \\
\hline$C 20: 2 n-6$ & 0.34 & / & & / & / & / \\
\hline$C 20: 4 n-6$ & 0.90 & I & & 0.69 & 1 & I \\
\hline$\Sigma n-6 P U F A$ & 13.31 & 34.31 & & 22.07 & 28.83 & 29.35 \\
\hline$n-3 / n-6 P U F A$ & 1.51 & 0.37 & & 0.54 & 0.49 & 0.53 \\
\hline
\end{tabular}


The water was oxygenated, passed through an artificial sponge ( $3 \mathrm{~cm}$ thickness) and through coral-sand ( $25 \mathrm{~cm}$ thickness) to remove chlorine. During the trial period, the diurnal cycle was $12 \mathrm{~h}$ light/12h dark. Water quality was monitored weekly and maintained as follows: temperature, $27.5 \pm 1.6^{\circ} \mathrm{C} ; \mathrm{pH}, 7.1 \pm 0.2$, respectively; ammonia nitrogen was lower than $0.05 \mathrm{mg} / \mathrm{L}$; dissolved oxygen was about $6.2 \mathrm{mg} / \mathrm{L}$. The fish were manually fed to satiation twice per day for 8 weeks. To calculate feed intake, uneaten feed was collected and dried $1 \mathrm{~h}$ after feeding.

Sampling and analytical methods. At the onset of the feeding trial, 18 fish were randomly sampled from the untreated fish, for analysis of whole body composition. After the 8 week experiment, 9 fish from each tank were randomly collected for proximate analysis, 3 for analysis of whole-body composition, and 6 were anesthetized with ice water to obtain weight of individual whole body, viscera, liver and intraperitoneal fat. White muscle from both sides of the fillets without the skin and liver were dissected, frozen immediately in liquid nitrogen, and stored at $-70^{\circ} \mathrm{C}$ until use.

Diets and fish samples (including white muscle and liver) were analyzed in triplicate for proximate composition. Crude protein, crude lipid, moisture, crude ash and gross energy (GE) were determined following standard methods (AOAC, 1984). Lipids for fatty acid analysis were extracted from diet ingredients, experimental diets, and muscle tissue with chloroform and methanol using the procedure of Bligh and Dyer (1959). Fatty acids were analyzed by gas chromatography-mass spectrometry (GC-MS) as previously described (Wei et al., 2009). The GC-MS analysis was carried out using an Agilent 6890 GC system equipped with an Agilent 5975 inert mass selective detector and an Agilent DB-23 capillary column ( $30 \mathrm{~m}$ length, $0.25 \mathrm{~mm}$ inner diameter, and $0.25 \mu \mathrm{m}$ film thickness). Ultra-high purity $(99.99 \%)$ helium was used as the carrier gas at a flow-rate of 1.0 $\mathrm{ml} / \mathrm{min}$. Sample volumes of $0.2 \mu \mathrm{l}$ were injected with a split ratio of $10: 1$. The injector and detector temperatures were $250^{\circ} \mathrm{C}$, and the solvent delay time was $4 \mathrm{~min}$. Oven temperature was kept at $110^{\circ} \mathrm{C}$ for $2 \mathrm{~min}$ and programmed to $220^{\circ} \mathrm{C}$ at a rate of $5^{\circ} \mathrm{C} / \mathrm{min}$, then held at $220^{\circ} \mathrm{C}$ for $5 \mathrm{~min}$. Fatty acids were identified by retention indices and by comparing their mass spectra with the NIST 05 spectral database. The relative percentages of individual fatty acids were calculated and expressed as mass percentages of total fatty acids.

Statistical analysis. All data are presented as mean $\pm \mathrm{S} . \mathrm{E}$, which were subjected to one-way ANOVA. When differences were significant, the treatment means were further compared with Duncan's multiple-range tests. All statistical analyses were performed using the SPSS software Ver. 20.0 for Windows (SPSS Inc., Chicago, IL, USA Ver 20.0, USA). Differences were considered significant at $\mathrm{P}<0.05$.

\section{Results}

After the 8 week feeding trial, there were no significant differences in survival among fish fed all the diets (Table 3 ). Different dietary lipid sources were found to have significantly $(P<0.05)$ influenced the growth performance in Anguilla marmorata juveniles. Weight gain (WG) and specific growth rate (SGR) of fish reared on FO and SBO diets were markedly higher than those fish fed the CO diet, while no other differences in WG and SGR were observed among other treatments. Fish fed FO and SBO diets had better feed utilization (feed conversion ratio, FCR) than those fed other diets, while fish fed PO diet showed the lowest feed utilization. 
Table 3 Effects of different lipid sources on growth performance and feed utilization of Anguilla marmorata $^{1}$

\begin{tabular}{llllll}
\hline \multirow{2}{*}{ Parameters } & Diets & & & \\
\cline { 2 - 5 } & FO & SFO & $P O$ & $C O$ & $S B O$ \\
\hline Initial weight (g) & $6.04 \pm 0.01$ & $6.01 \pm 0.06$ & $5.94 \pm 0.02$ & $6.03 \pm 0.05$ & $6.02 \pm 0.02$ \\
Final weight (g) & $12.9 \pm 0.22^{\mathrm{ab}}$ & $11.5 \pm 0.12^{\mathrm{abc}}$ & $11.1 \pm 0.50^{\mathrm{bc}}$ & $10.5 \pm 1.42^{\mathrm{c}}$ & $13.5 \pm 0.24^{\mathrm{a}}$ \\
WG $^{2}(\%)$ & $114.2 \pm 4.05^{\mathrm{a}}$ & $90.5 \pm 3.08^{\mathrm{ab}}$ & $87.2 \pm 8.21^{\mathrm{ab}}$ & $74.3 \pm 23.12^{\mathrm{b}}$ & $123.8 \pm 4.00^{\mathrm{a}}$ \\
$\mathrm{SGR}^{3}\left(\%\right.$ day $\left.^{-1}\right)$ & $1.27 \pm 0.03^{\mathrm{a}}$ & $1.07 \pm 0.03^{\mathrm{ab}}$ & $1.04 \pm 0.07^{\mathrm{ab}}$ & $0.90 \pm 0.22^{\mathrm{b}}$ & $1.34 \pm 0.03^{\mathrm{a}}$ \\
$\mathrm{FE}^{4}(\%)$ & $2.08 \pm 0.07^{\mathrm{a}}$ & $1.66 \pm 0.04^{\mathrm{bc}}$ & $1.53 \pm 0.06^{\mathrm{b}}$ & $1.74 \pm 0.02^{\mathrm{c}}$ & $2.00 \pm 0.04^{\mathrm{a}}$ \\
FCR $^{5}$ & $1.53 \pm 0.05^{\mathrm{c}}$ & $1.93 \pm 0.05^{\mathrm{b}}$ & $2.09 \pm 0.08^{\mathrm{a}}$ & $1.85 \pm 0.02^{\mathrm{b}}$ & $1.61 \pm 0.03^{\mathrm{c}}$ \\
Feed intake $^{6} \mathrm{~g}$ & $8.11 \pm 0.67$ & $9.29 \pm 0.92$ & $7.41 \pm 1.61$ & $7.16 \pm 1.96$ & $8.93 \pm 1.26$ \\
Survival rate $^{7}(\%)$ & $84.5 \pm 2.2$ & $93.3 \pm 3.85$ & $82.2 \pm 4.45$ & $93.3 \pm 3.85$ & $82.2 \pm 4.45$ \\
VSI $^{8}(\%)$ & $5.67 \pm 0.18^{\mathrm{b}}$ & $6.49 \pm 0.19^{\mathrm{a}}$ & $5.92 \pm 0.24^{\mathrm{ab}}$ & $5.81 \pm 0.24^{\mathrm{ab}}$ & $6.20 \pm 0.30^{\mathrm{ab}}$ \\
$\mathrm{HSI}^{9}(\%)$ & $1.34 \pm 0.09^{\mathrm{bc}}$ & $1.65 \pm 0.10^{\mathrm{a}}$ & $1.40 \pm 0.06^{\mathrm{bc}}$ & $1.54 \pm 0.07^{\mathrm{ab}}$ & $1.29 \pm 0.08^{\mathrm{c}}$ \\
IPF $^{10}(\%)$ & $1.17 \pm 0.16$ & $1.19 \pm 0.19$ & $1.17 \pm 0.19$ & $1.10 \pm 0.13$ & $1.31 \pm 0.18$ \\
CF $^{11}(\%)$ & $2.42 \pm 0.33^{\mathrm{a}}$ & $2.45 \pm 0.45^{\mathrm{a}}$ & $2.21 \pm 0.34^{\mathrm{a}}$ & $1.79 \pm 0.45^{\mathrm{b}}$ & $2.32 \pm 0.21^{\mathrm{a}}$ \\
\hline
\end{tabular}

${ }^{1}$ Values (mean \pm S.E. of three replications) in the same row with different superscript letters are significantly different $(P<0.05)$.

${ }^{2}$ Weight gain $(W G, \%)=100 \times$ (final weight-initial weight)/(initial weight).

${ }^{3}$ Specific growth rate $\left(\mathrm{SGR}, \% \mathrm{day}^{-1}\right)=100 \times[\operatorname{Ln}$ (final weight) $-\operatorname{Ln}$ (initial weight) $] /$ (days of feeding trial).

${ }^{4}$ Feed efficiency $(\mathrm{FE}, \%)=100 \times$ (final weight-initial weight)/(total dry weight of feed fed)

${ }^{5} \mathrm{FCR}$, feed conversion ratio $=$ Feed consumed $/$ Body weight gain

${ }^{6}$ Feed intake.

${ }^{7}$ Survival rate $(\mathrm{SR}, \%)=100 \times$ (final fish number) $/$ (initial fish number).

${ }^{8}$ Viscerosomatic index $($ VSI $)=100 \times$ (visceral weight $) /$ (body weight) .

${ }^{9}$ Hepatosomatic index $(\mathrm{HSI})=100 \times$ (liver weight)/(body weight).

${ }^{10}$ Intraperitoneal fat ratio (IPF) $=100 \times$ (intraperitoneal weight)/(body weight).

${ }^{11}$ Condition factor $(\mathrm{CF})=100 \times$ (body weight)/(body length ${ }^{3}$ ).

The Viscerosomatic index (VSI) and Hepatosomatic index (HSI) of fish fed FO diet were significantly lower than fish fed SFO diet. There were no other differences in VSI and HSI compared to other treatments. Condition factor (CF) of fish fed an FO diet was markedly higher than fish fed a CO diet.

The proximate composition of whole body and muscle of the Anguilla marmorata are shown in Table 4. The whole body protein content of fish fed FO was significantly higher than that of the fish fed SBO diet; the whole body lipid content moisture showed an opposite trend. For white muscle composition, no significant differences were found between treatments.

Table 4 Effect of different lipid sources on whole body and muscle composition of Anguilla marmorata (\%)

\begin{tabular}{llllll}
\hline Parameters & Diets & \multicolumn{5}{l}{} \\
\cline { 2 - 6 } & FO & SFO & PO & CO & SBO \\
\hline Whole body & composition & & & & \\
Moisture & $70.29 \pm 0.05$ & $68.18 \pm 1.15$ & $67.89 \pm 0.50$ & $68.30 \pm 1.46$ & $66.81 \pm 0.67$ \\
Protein & $16.14 \pm 0.17^{\mathrm{a}}$ & $15.84 \pm 0.10^{\mathrm{ab}}$ & $15.84 \pm 0.14^{\mathrm{ab}}$ & $15.96 \pm 0.14^{\mathrm{ab}}$ & $15.67 \pm 0.08^{\mathrm{b}}$ \\
Lipid & $10.88 \pm 0.28^{\mathrm{b}}$ & $12.15 \pm 0.66^{\mathrm{ab}}$ & $12.34 \pm 0.58^{\mathrm{ab}}$ & $12.12 \pm 0.96^{\mathrm{ab}}$ & $13.91 \pm 0.39^{\mathrm{a}}$ \\
Muscle composition & & & & \\
Moisture & $65.68 \pm 0.57$ & $64.80 \pm 1.56$ & $63.90 \pm 1.36$ & $66.14 \pm 1.18$ & $67.38 \pm 0.75$ \\
Protein & $17.34 \pm 0.15$ & $18.58 \pm 0.78$ & $18.62 \pm 1.01$ & $16.83 \pm 0.43$ & $17.59 \pm 0.13$ \\
Lipid & $14.50 \pm 0.33$ & $13.46 \pm 0.30$ & $14.63 \pm 0.56$ & $14.47 \pm 0.94$ & $12.94 \pm 0.46$ \\
\hline
\end{tabular}

Values (mean \pm S.E. of three replications) in the same row with different superscript letters are significantly different $(P<0.05)$.

Muscle fatty acid composition is shown in Table 5 . Muscle from fish fed the FO diet had significantly higher levels of $C 20: 5 n-3$ and $n-3 / n-6$ ratio compared to that of fish fed vegetable oil (VO) diets, while muscle n-6 PUFA and C18:2n-6 content showed an 
opposite trend. Muscle C22:6n-3 content of fish fed FO diet was significantly higher than that fed PO diet. The content of n-3PUFA of fish fed FO diet was markedly higher than that of fish fed VO diets (except the SBO diet).

Table 5 Effects of different lipid sources on fatty acid composition in muscle of Anguilla marmorata(\%)

\begin{tabular}{|c|c|c|c|c|c|}
\hline \multirow{2}{*}{ Fatty acid } & \multicolumn{5}{|l|}{ Diets } \\
\hline & $F O$ & SFO & $P O$ & $\mathrm{CO}$ & SBO \\
\hline C14:0 & $3.01 \pm 0.03^{a}$ & $2.63 \pm 0.11^{b}$ & $2.65 \pm 0.10^{b}$ & $2.49 \pm 0.14^{b}$ & $2.39 \pm 0.12^{b}$ \\
\hline C15:0 & $1.07 \pm 0.03$ & $1.04 \pm 0.17$ & $1.07 \pm 0.08$ & $0.86 \pm 0.18$ & $0.75 \pm 0.14$ \\
\hline C16:0 & $1.07 \pm 0.03^{a}$ & $1.04 \pm 0.17^{\mathrm{ab}}$ & $1.07 \pm 0.08^{a}$ & $0.86 \pm 0.18^{a b}$ & $0.75 \pm 0.14^{b}$ \\
\hline C17:0 & $1.83 \pm 0.12^{a}$ & $1.87 \pm 0.15^{\mathrm{a}}$ & $1.91 \pm 0.20^{\mathrm{a}}$ & $1.49 \pm 0.18^{\mathrm{ab}}$ & $1.19 \pm 0.03^{b}$ \\
\hline C18:0 & $4.11 \pm 0.03^{\mathrm{ab}}$ & $4.47 \pm 0.11^{a}$ & $4.10 \pm 0.04^{\mathrm{ab}}$ & $3.82 \pm 0.14^{b}$ & $4.30 \pm 0.18^{a}$ \\
\hline$\Sigma S F A$ & $29.9 \pm 0.51^{a}$ & $28.7 \pm 0.94^{\mathrm{ab}}$ & $29.7 \pm 0.46^{a}$ & $27.8 \pm 1.06^{\mathrm{ab}}$ & $26.9 \pm 0.20^{b}$ \\
\hline C16:1 & $4.44 \pm 0.08^{a b}$ & $5.53 \pm 0.47^{a}$ & $4.72 \pm 0.55^{\mathrm{ab}}$ & $4.17 \pm 0.84^{\mathrm{ab}}$ & $3.28 \pm 0.28^{b}$ \\
\hline C18:1 & $32.1 \pm 2.32$ & $29.5 \pm 0.66$ & $32.5 \pm 0.53$ & $31.6 \pm 1.09$ & $28.9 \pm 1.75$ \\
\hline$\Sigma M U F A$ & $36.5 \pm 2.40$ & $35.4 \pm 0.42$ & $37.3 \pm 0.17$ & $35.8 \pm 1.47$ & $32.2 \pm 1.47$ \\
\hline$C 18: 3 n-3$ & $0.58 \pm 0.03^{b}$ & / & / & / & $1.07 \pm 0.03^{a}$ \\
\hline$C 20: 5 n-3$ & $1.39 \pm 0.08^{a}$ & $1.06 \pm 0.09^{b}$ & $1.03 \pm 0.07^{b}$ & $1.02 \pm 0.02^{\mathrm{b}}$ & $1.12 \pm 0.06^{b}$ \\
\hline$C 22: 6 n-3$ & $3.02 \pm 0.30^{a}$ & $2.32 \pm 0.09^{\mathrm{ab}}$ & $2.11 \pm 0.22^{b}$ & $2.47 \pm 0.13^{a b}$ & $2.60 \pm 0.39^{\mathrm{ab}}$ \\
\hline$\Sigma n-3 P U F A$ & $4.99 \pm 0.40^{a}$ & $3.39 \pm 0.04^{b c}$ & $3.14 \pm 0.28^{b}$ & $3.49 \pm 0.12^{b c}$ & $4.42 \pm 0.50^{\mathrm{ac}}$ \\
\hline C18:2n-6 & $5.05 \pm 0.12^{c}$ & $9.40 \pm 0.85^{\mathrm{a}}$ & $6.17 \pm 0.48^{b c}$ & $8.34 \pm 0.61^{a b}$ & $10.4 \pm 1.11^{a}$ \\
\hline$C 20: 2 n-6$ & / & $1.12 \pm 0.16$ & $1.03 \pm 0.20$ & $0.72 \pm 0.07$ & $0.69 \pm 0.03$ \\
\hline$C 20: 4 n-6$ & $1.65 \pm 0.26$ & $1.91 \pm 0.10$ & $1.98 \pm 0.18$ & $1.59 \pm 0.16$ & $1.71 \pm 0.51$ \\
\hline$\Sigma n-6 P U F A$ & $6.69 \pm 0.24^{d}$ & $12.4 \pm 0.60^{\mathrm{ab}}$ & $9.18 \pm 0.22^{c}$ & $11.1 \pm 0.81^{\mathrm{ab}}$ & $12.8 \pm 0.24^{a}$ \\
\hline$n-3 / n-6 P U F A$ & $0.75 \pm 0.08^{a}$ & $0.27 \pm 0.01^{b}$ & $0.34 \pm 0.02^{b}$ & $0.33 \pm 0.02^{b}$ & $0.37 \pm 0.06^{b}$ \\
\hline
\end{tabular}

Values (mean \pm S.E. of three replications) in the same row with different superscript letters are significantly different $(P<0.05)$.

\section{Discussion}

In this study, all the experimental diets were readily accepted by the fish. No significant differences in survival were found between fish fed the FO and VO diets. Weight gain of fish fed different dietary lipid sources are in general accordance with earlier observations (Reyes et L., 2016; Luo et al., 2013). Similar reports have been published for seabream and seabass (Izquierdo et al., 2003), grouper Epinephelus coioides (Lin et al., 2007), and turbot (Regost et al., 2003). Fish fed the CO, PO, and SFO diets showed significantly lower feed utilization compared to those fed the FO and SBO diets. This suggests that $\mathrm{CO}, \mathrm{PO}$, and SBO may be unsuitable as complete fish oil substitution for Anguilla marmorata.

Fatty acid composition of fish muscle is directly related to dietary fatty acid composition (Dernekbaşi et al. 2011, Bell et al., 2004, Caballero et al., 2002, Izquierdo et al., 2003). In contrast to FO, VO lacks n-3 HUFA, such as EPA and DHA, and is characterised by a low n-3 / n-6 ratio. Muscle of fish fed VO diets showed a lower content of EPA, DHA and n-3PUFA compared to that of fish fed an FO diet. Similar results have been shown in almost all finfish species, from carnivorous to herbivorous species and from marine cold water to tropical freshwater species fed with vegetable oil (Lin et al., 2007, Izquierdo et al., 2003, Caballero et al., 2002, Du et al., 2008). The present results confirm this relationship between dietary fatty acid and muscle fatty acid content. More evidence suggests that n-3 HUFA is extremely beneficial to human health, for prevention of cardiovascular and auto-immune diseases (Ruxton et al., 2005, Sinclair et al., 2007). The reduction of $n-3$ HUFA, such as EPA and DHA, in fish muscle should be taken into account in human nutrition. Present results indicate that the nutritional value of fish fed $\mathrm{SFO}, \mathrm{PO}$, and $\mathrm{CO}$ diets is significantly reduced compared to that of fish fed an FO diet. 


\section{Conclusion}

In conclusion, our results confirm that soybean oil may be appropriate as an alternative to fish oil with full substitution in fish meal-based diets for eel without a negative effect on growth performance and feed utilization. The inclusion of corn oil, peanut oil, and sunflower oil would result in poor feed utilization by eel.

\section{Acknowledgements}

This work was financially supported by Key Laboratory of Tropical \&Subtropical Fishery Resource Application and Cultivation Ministry of Agriculture P.R.China, the fund of National Natural Science Foundation of China (Grant Nos.\#31202007), National Key Technology Support Program (2012BAD25B03) and Administration of Ocean and fisheries of Guangdong Province (Grant Nos.\# A201201G01, A201601C08).

\section{References}

AOAC, 1984. Official Methods of Analysis,14th edn, Arlington, VA.

Asdari R., ALIYU-PAIKO M., Hashim R. and Ramachandran S, 2011. Effects of different dietary lipid sources in the diet for Pangasius hypophthalmus (Sauvage, 1878) juvenile on growth performance, nutrient utilization, body indices and muscle and liver fatty acid composition. Aquacult Nutr., 17: 44-53.

Bell J.G., Henderson R.J., Tocher D.R. and Sargent J.R, 2004. Replacement of dietary fish oil with increasing levels of linseed oil: modification of flesh fatty acid compositions in Atlantic salmon (Salmo salar) using a fish oil finishing diet. Lipids, 39: 223-232.

Bligh E.G. and Dyer W.J, 1959. A rapid method of total lipid extraction and purification. Canadian J Biochem Physiol., 37: 911-917.

Caballero M., Obach A., Rosenlund G., Montero D., Gisvold M. and Izquierdo M, 2002. Impact of different dietary lipid sources on growth, lipid digestibility, tissue fatty acid composition and histology of rainbow trout, Oncorhynchus mykiss. Aquaculture: 214, 253-271.

Dernekbaşi S.*, Karayücel İ., Öksüz A., 2011. Effect of Dietary Canola Oil Level on Fatty Acid Composition of Rainbow Trout (Oncorhynchus mykiss L.), Isr. J. Aquacult.Bamidgeh, IIC:63.2011.535. 11 pages.

Du Z., Clouet P., Huang L., Degrace P., Zheng W., He J., Tian L. and Liu Y, 2008. Utilization of different dietary lipid sources at high level in herbivorous grass carp (Ctenopharyngodon idella): mechanism related to hepatic fatty acid oxidation. Aquacult Nutr., 14, 77-92.

Engin K. and Carter C, 2001. Ammonia and urea excretion rates of juvenile Australian short-finned eel (Anguilla australis australis) as influenced by dietary protein level. Aquaculture, 194:123-136.

FAO ed, 2010. 2008 FAO year book annuaire: Fishery and aquaculture statistics, FAO, Rome.

Geejm V.d., JC R. and S D, 2009. Spawning migration of the European eel: reproduction index, a useful tool for conservation management. Springer, Dordecht, The Netherlands.

Ghanawi J., Roy L., Davis D.A. and Saoud I.P, 2011. Effects of dietary lipid levels on growth performance of marbled spinefoot rabbit fish Siganus rivulatus. Aquaculture, 310: 395-400.

Higgs D. and Dong F, 2000. Lipids and fatty acids. The encyclopedia of aquaculture. New York, USA, John Wiley and Sons, 476-496.

Izquierdo M., Obach A., Arantzamendi L., Montero D., Robaina L. and Rosenlund G, 2003. Dietary lipid sources for seabream and seabass: growth performance, tissue composition and flesh quality. Aquacult Nutr., 9: 397-407.

Lee W.-C., Chen Y.-H., Lee Y.-C. and Liao I.C, 2003. The competitiveness of the eel aquaculture in Taiwan, Japan, and China. Aquaculture, 221:115-124. 
Lin H.Z., Liu Y.J., He J.G., Zheng W.H. and Tian L.X, 2007. Alternative vegetable lipid sources in diets for grouper, Epinephelus coioides (Hamilton): effects on growth, and muscle and liver fatty acid composition. Aquacult Res., 38:1605-1611.

Luo M., Guan R., Li Z. and Jin, H, 2013. The effects of water temperature on the survival, feeding, and growth of the juveniles of Anguilla marmorata and A. bicolor pacifica. Aquaculture, 400: 61-64.

Montero D., Kalinowski T., Obach A., Robaina L., Tort L., Caballero M. and Izquierdo M, 2003. Vegetable lipid sources for gilthead seabream (Sparus aurata): effects on fish health. Aquaculture, 225: 353-370.

Regost C., Arzel J., Robin J., Rosenlund G. and Kaushik S, 2003. Total replacement of fish oil by soybean or linseed oil with a return to fish oil in turbot (Psetta maxima): 1. Growth performance, flesh fatty acid profile, and lipid metabolism. Aquaculture, 217: 465-482.

Reyes M. L. E., Velázquez E.A.R., Hernández L.H.H.*, Araiza. A.F., 2015. The effect of the substitution of fish oil with a mixture of plant-origin oils in diets of rainbow trout (Oncorhynchus mykiss Walbaum) fingerlings on growth, phosphorus and nitrogen excretion, 9 pages. Isr. J.Aquacult.-Bamidgeh, 67.2015.1217,

Ruxton C., Calder P., Reed S.C. and Simpson M, 2005. The impact of long-chain n-3 polyunsaturated fatty acids on human health. Nutrition Research Reviews, 18:113-129.

Sinclair A.J., Begg D., Mathai M. and Weisinger R.S, 2007. Omega 3 fatty acids and the brain: review of studies in depression. Asia Pacific J Clin Nutr., 16: 391-397.

Tsukamoto K., Aoyama J. and Miller M.J, 2009. Present status of the Japanese eel: resources and recent research In Eels at the edge: science, status and conservation concerns. American Fisheries Society Symposium, Bethesda, pp. 21-35.

Turchini G.M., Torstensen B.E. and Ng W.K, 2009. Fish oil replacement in finfish nutrition. Rev Aquacult., 1: 10-57.

Wei A., Zhang X., Wei D., Chen G., Wu Q. and Yang S.T, 2009. Effects of cassava starch hydrolysate on cell growth and lipid accumulation of the heterotrophic microalgae Chlorella protothecoides. J Indust. Microbiol.Biotechnol., 36: 1383-1389. 